\title{
FOUR-YEAR MONTHLY SEDIMENT DEPOSITION ON TURBID SOUTHWESTERN ATLANTIC CORAL REEFS, WITH A COMPARISON OF BENTHIC ASSEMBLAGES
}

\author{
Clovis Barreira e Castro ${ }^{1 *}$, Bárbara Segal ${ }^{1,2}$, Fábio Negrão $^{3}$ and Emiliano Nicolas Calderon ${ }^{l}$ \\ ${ }^{1}$ Universidade Federal do Rio de Janeiro \\ Museu Nacional, Departamento de Invertebrados \\ (Quinta da Boa Vista, s/n, 20940-040 Rio de Janeiro, RJ, Brasil) \\ ${ }^{2}$ Universidade Federal de Santa Catarina \\ Departamento de Ecologia e Zoologia - CCB \\ (Edifício Fritz Muller, 88040-970 Florianópolis, SC, Brasil) \\ ${ }^{3}$ Aratur Mergulho Ecoturismo \\ (Rua Sete de Setembro, 88, 45900-000 Caravelas, BA, Brasil) \\ *Corresponding author: clovis.castro@ coralvivo.org.br
}

\section{A B S T R A C T}

High sedimentation is often related to stress in coral reef communities. Most southwestern Atlantic reefs are characterized by high sedimentation. However, there are no temporal series of sediment deposition rates. We evaluated sediment deposition, the sediment carbonate composition and coral and zoanthid covers on six reefs in Brazil over four-years. Sediment deposition rates varied from near zero to $233 \mathrm{mg} \mathrm{cm}^{-2} \mathrm{day}^{-1}$, with peaks between August and December, and yearly averages ranging from nine to $104 \mathrm{mg} \mathrm{cm}^{-2} \mathrm{day}^{-1}$. Deposition rates presented site-specific correlations with wind, indicating that resuspension must be a major factor. The presence of carbonates varied from $38 \%$ to $90 \%$, with two sites showing seasonal differences. Benthic communities were fairly similar among sites, but the analyses suggested particular frequencies at each site. There was no significant correlation between sediment and benthic communities. However, Palythoa caribaeorum usually occur in high sediment deposition areas. Our results did not corroborate previous data that suggested that a $10 \mathrm{mg} \mathrm{cm}^{-2}$ day $^{-1}$ would be a "critical limit for coral survival". Some coral reefs may be associated with high sedimentation environments including carbonatic fractions, but which does not per se hinder the development of southwestern Atlantic coral reef communities.

\section{RESUMO}

A sedimentação é freqüentemente relacionada a estresse em recifes de coral. Os recifes do Atlântico sul ocidental possuem grande sedimentação, entretanto carecem de séries temporais das taxas de deposição de sedimento. Foram avaliadas estas taxas e a composição carbonática do sedimento, além da cobertura de corais e zoantídeos em seis recifes brasileiros durante quatro anos consecutivos. A deposição variou de zero a $233 \mathrm{mg} \mathrm{cm}^{-2} \mathrm{dia}^{-1}$, com picos entre agosto e dezembro e médias anuais variando de nove a $104 \mathrm{mg}$ $\mathrm{cm}^{-2} \mathrm{dia}^{-1}$. As taxas de deposição apresentaram correlação com o vento, indicando que a ressuspensão deve ser o fator preponderante. A contribuição do carbonato variou de $38 \%$ a $90 \%$, com dois locais apresentando diferenciação sazonal. As comunidades bênticas foram similares entre locais, entretanto as análises sugerem freqüencias diferenciadas para cada local. Não houve correlação significativa entre sedimentação e a comunidade bêntica. Entretanto, maior cobertura de Palythoa caribaeorum normalmente ocorreu em áreas de maior sedimentação. Nossos resultados não corroboraram resultados prévios sugerindo que $10 \mathrm{mg}$ $\mathrm{cm}^{-2} \mathrm{dia}^{-1}$ seria "limite crítico para sobrevivência" dos corais. Recifes brasileiros podem estar associados a ambientes de alta deposição de sedimento com elevadas frações carbonáticas, o que não impede o desenvolvimento das comunidades recifais do Atlântico sul ocidental.

Descriptors: Benthic communities, Coral, Coral reef, Environmental conditions, Sedimentation, Zoanthid. Descritores: Comunidade bêntica, Coral, Recife de coral, Condições ambientais, Sedimentação, Zoantídeo.

\section{INTRODUCTION}

Sedimentation, whether by suspension or deposition on the reefs, is considered one of the major causes of stress to coral communities (ROGERS, 1990). High levels of sedimentation have been associated with coral smothering, abrasion, shadowing, and/or recruitment inhibition in the Caribbean and the Indo-Pacific Oceans (HUBBARD, 1997). High sedimentation in reef areas has also been related to changes in coral recruitment (MAIDA et al., 1994), coral skeleton morphology (FOSTER, 1980), coral growth (DODGE et al., 1974; DODGE; VAISNYS, 1977), and community structure 
(CORTÉS; RISK, 1985; TOMASCIK; SANDER, 1987), leading to lethal or sub-lethal effects (ROGERS, 1983). Most studies, however, were carried out in clear water regions of the Caribbean Sea and Indo-Pacific Ocean, which are distinct from the turbid reef environments predominant in the southwestern Atlantic ocean. Moreover, the interference of sedimentation in coral ecology, especially that related to human activity, varies according to the reef environment (BROWN, 1997).

It has been stated that usual sediment deposition rates on coral reefs would be around $10 \mathrm{mg}$ $\mathrm{cm}^{-2}$ day ${ }^{-1}$; reefs under moderate to severe sedimentation would present rates between 10 and 50 $\mathrm{mg} \mathrm{cm}^{-2}$ day $^{-1}$, and reefs under severe to catastrophic conditions would have rates higher than $50 \mathrm{mg} \mathrm{cm}^{-2}$ day $^{-1}$ (Pastorak; Bilyard, 1985 apud BROWN, 1997; ROGERS 1990). However, reef communities flourishing in high suspended sediment (LARCOMBE et al., 2001) or high sediment deposition environments (ANTHONY; LARCOMBE, 2002) occur in various regions of the world. Environmental conditions on high turbidity reefs do not always have a negative impact on corals, with species-specific responses (ANTHONY, 2006; SOFONIA; ANTHONY, 2008). Some reef corals may even have evolved in high sedimentation environments (POTTS; JACOBS, 2002). Nevertheless, the understanding of the relationship between reef coral communities and sedimentation is still fragmentary in all regions of the world.

A relationship between the high sedimentation occurring on Brazilian reefs and their low coral diversity, coupled with high levels of endemism, has been suggested ever since last century (see LABOREL, 1970; LEÃO; GINSBURG, 1997). Leão et al. (1997) hypothesized that high sedimentation over the past 3,000 years might be responsible for a massive decline in coral cover and for changes in species dominance in reefs near Salvador, Brazil. However, the relation between sedimentation and coral communities in the South Atlantic has not yet been soundly established, a situation that is further complicated by the lack of temporal series of sediment deposition on those reefs (see GARZÓN-FERREIRA et al., 2002). Dutra et al. (2006) presented biotic and sediment deposition data for two sampling periods (March and October) from five stations in the Abrolhos area (eastern Brazil). They indicated a threshold accumulation rate of $10 \mathrm{mg}$ $\mathrm{cm}^{-2}$ day $^{-1}$ for maintenance of the vitality of these reefs.

We evaluated sediment deposition and coral communities on inner reefs of the Abrolhos Bank, quantifying (1) sediment deposition rates over a fouryear time span on reefs with different sediment signatures, (2) the carbonate composition of the deposited sediment, and (3) total and specific coral and zoanthid cover. Sedimentation was correlated with wind frequency, average and peak speeds, positively or negatively depending on station position in the reef, and benthic assemblages. Our results bring new information, different from previous studies (DUTRA et al. 2006), showing equivalent coral community cover even in localities with extremely high sediment deposition.

\section{Material And Methods \\ Site Selection and Survey}

We sought to study sites where corals represented a considerable part of the benthos. Sites and stations were, therefore, chosen as being visibly the most developed coral communities in each area. These areas were chosen by visual surveys along reef borders. Large elevations or depressions were avoided to facilitate the use of line transects. All survey sites are situated approximately between five and $16 \mathrm{~km}$ offshore (Fig. 1), on the so-called Abrolhos inner reefs. All stations were located near reef tops (uncovered at low tide), adjacent to the margin (less than $10 \mathrm{~m}$ from it), except where otherwise stated.

\section{Guaratibas Reefs}

Elongated bank reefs, approximately parallel to the coastline. The western side of the reef was almost completely covered with foliose algae, with sparse coral heads; the eastern side presented high wave energy. Stations were established in the southern area $\left(17^{\circ} 26.204^{\prime} \mathrm{S}, 039^{\circ} 08.038^{\prime} \mathrm{W}\right)$, which presented comparatively higher coral cover. Based on monthly inspections, these stations were found to be exposed to wave action due to southerly winds, but protected from northeasterly winds (except during high tide). The reef's crest is exposed at low tide. Stations were set below the low water mark, less than $5 \mathrm{~m}$ away from the exposed crest. The base of the reef is approximately $4.7 \mathrm{~m}$ deep at low tide.

\section{Pedra Lixa}

It is located on the north of Parcel das Paredes, the largest reef of the Abrolhos Bank (17 ${ }^{\circ} 41.535^{\prime}$ S, $\left.038^{\circ} 58.608^{\prime} W\right)$. Stations were located on the margin of a large bank, surrounded by smaller pinnacles, protected from waves due to southerly winds, except during high tide, and partially exposed to waves due to northeasterly winds. The reef's crest is exposed at low tide. Stations were below the low water mark, well away (> $100 \mathrm{~m}$ ) from the exposed crest. Depth at the reef's base is approximately $6.3 \mathrm{~m}$ at low tide. 


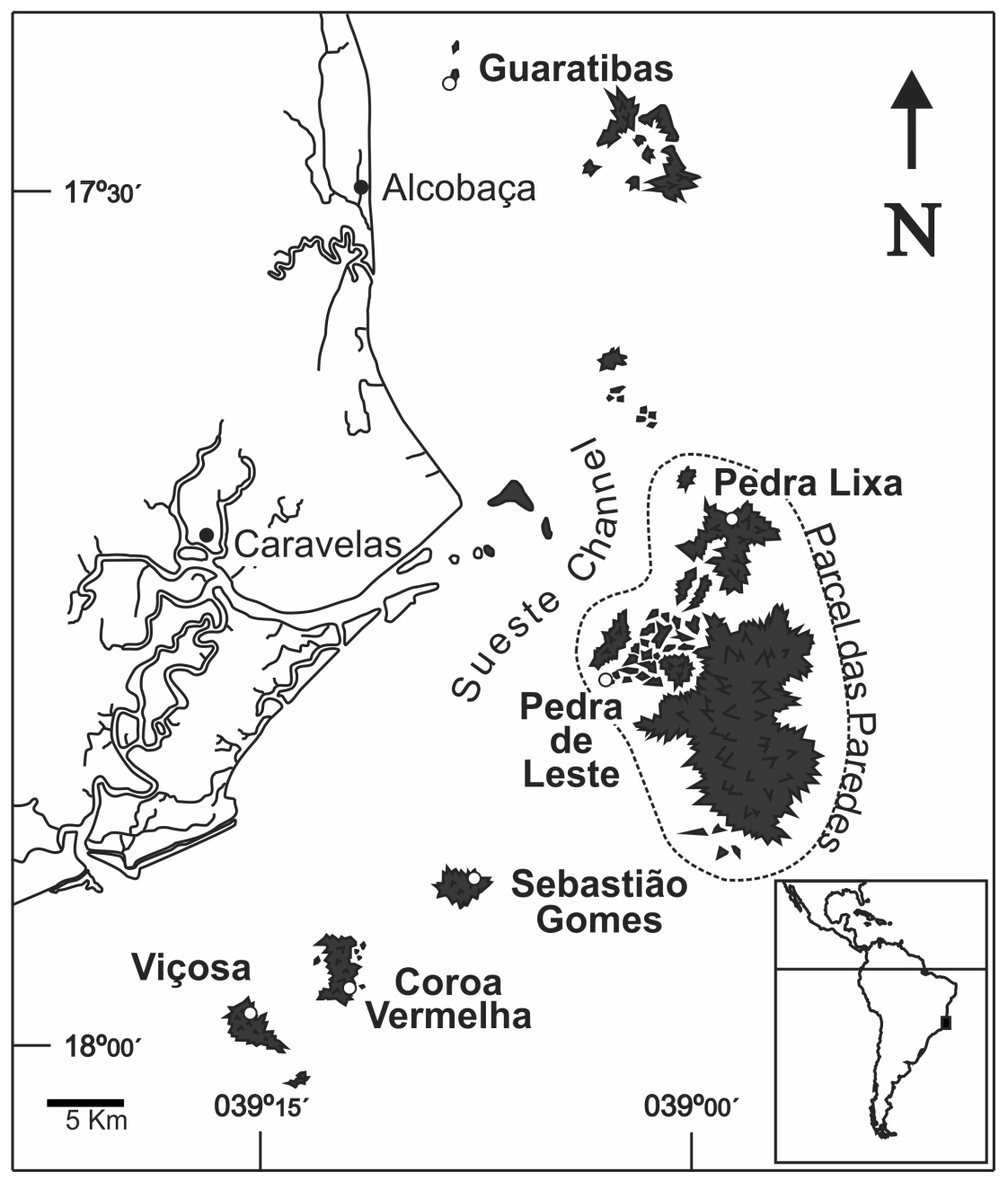

Fig. 1. Map of the Abrolhos inner reefs, showing the position of the studied sites.

Pedra de Leste

It is located in the southwestern area of Parcel das Paredes reef $\left(17^{\circ} 47.169^{\prime} \mathrm{S}, 039^{\circ} 02.979^{\prime} \mathrm{W}\right)$. Stations were located on a large bank, directly exposed to waves due to southerly winds, but protected from northeasterly winds. The three stations were separated by grooves on the reef's margin. The reef's crest is exposed at low tide. Stations were below the low tide mark, well away (> $100 \mathrm{~m}$ ) from the exposed crest. Depth at the reef's base attained $11 \mathrm{~m}$ at low tide, with a nearly vertical wall.

\section{Sebastião Gomes}

A bank reef located $15 \mathrm{~km}$ south of Parcel das Paredes and $5 \mathrm{~km}$ north of Coroa Vermelha. The reef is elliptic in shape. Sampling site $\left(17^{\circ} 54.158^{\prime} \mathrm{S}\right.$, $039^{\circ} 07.568^{\prime} \mathrm{W}$ ) was partially protected from waves due to southerly winds (except during strong high tides) and exposed to waves due to northeasterly winds. The reef edge presents several shallow spurs and grooves at the sampling site, up to $60 \mathrm{~m}$ long and c. $10 \mathrm{~m}$ wide. The reef's crest is exposed at low tide. Stations were below the low tide mark, less than $10 \mathrm{~m}$ away from the exposed crest. The reef's base is very shallow, between 1.5 and $2.5 \mathrm{~m}$ deep at low tide. Sebastião Gomes is the only completely isolated sampling site, surrounded by depths over $10 \mathrm{~m}$.

\section{Coroa Vermelha}

A bank reef of irregular outline. There is a small sandy cay ( $300 \mathrm{~m}$ long, $100 \mathrm{~m}$ wide and $1.5 \mathrm{~m}$ above mean sea level) on the southern part of the bank. The study site was located on the southeastern

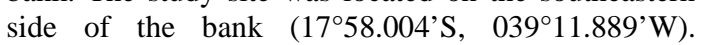


Stations were set up on the northern margin of a channel that runs perpendicular to the reef margin; the channel's southern margin presented only sparse coral heads. The site offered protection from the wind and waves similar to that on Sebastião Gomes. It was the site most exposed to easterly winds. The stations were below the low tide mark, less than $10 \mathrm{~m}$ away from the exposed crest. Depth at reef basis varied between 3.7 and $4.2 \mathrm{~m}$ at low tide.

\section{Viçosa}

The southernmost bank reef in the south Atlantic, located some $2.5 \mathrm{~km}$ south of Coroa Vermelha. The study site was located on the northern margin of the reef $\left(17^{\circ} 58.873^{\prime} \mathrm{S}, 039^{\circ} 15.338^{\prime} \mathrm{W}\right)$, facing the channel between the Coroa Vermelha and Viçosa reefs and closer to the western entrance of this channel. It was protected from waves due to southerly winds (except during high tides) and exposed to those due to northeasterly winds. The reef's crest is exposed at low tide. Stations were below the low water mark, less than $20 \mathrm{~m}$ away from the exposed crest. Depth at reef's base varied between 1.8 and $3.8 \mathrm{~m}$.

\section{Sediment Deposition}

Ten sediment traps were fixed to each reef site among coral cover stations, using iron bars. Sediment traps were made of PVC tubes, $7 \mathrm{~cm}$ in diameter by $25 \mathrm{~cm}$ in height (see BLOMQVIST; KOFOED, 1981). The tops of the sediment traps were between 0.2 and $2.9 \mathrm{~m}$ deep at low spring tide. They were submerged during consecutive periods of from 21 to 37 days. Sediments were placed into preweighed containers, repeatedly rinsed with freshwater to remove the salt content, and placed in a drying oven at a low temperature $\left(<100^{\circ} \mathrm{C}\right)$. During the drying period, samples were weighed daily using a 2digit precision scale (Marte AS5500C), and returned to the oven at intervals until the consecutive weights were less than $0.15 \mathrm{mg}$ apart (this difference would represent less than $1 \mathrm{mg} \mathrm{cm}^{-2} \mathrm{day}^{-1}$ in the final rate). Outliers were detected using standard boxplot procedures for normal data, where non-outlying observations fell inside the interval $\mathrm{Q}_{1}-1.5 \mathrm{IQR}$, $\mathrm{Q}_{3}+1.5 \mathrm{IQR}$, with IQR $=\mathrm{Q}_{3}-\mathrm{Q}_{1}$ (DYTHAM, 1999). Only lower outliers were removed from the analysis. This procedure was adopted since fishes (Stegastes sp.) and crabs were observed inhabiting some sediment traps, which had less sediment in them than others.

\section{Sediment Carbonate Content}

Subsamples of the deposited sediments were used for carbonate content analysis. Four to ten samples were used from each reef from OctoberNovember/2001 and March/2002, periods which represent high and low sediment depositions, respectively. Approximately $0.5 \mathrm{~g}$ of sediment was collected from each sample and transferred to a plastic tube. Subsamples were treated with a solution of $10 \%$ formic acid and 5\% formalin to dissolve their carbonate fraction. After dissolution, subsamples were repeatedly rinsed in freshwater to remove all residues from the solution, dried and weighed as indicated in subsection Sediment Deposition. Carbonate composition (\%) was calculated by the relationship between weight loss and initial subsample weight.

\section{Wind}

Data on wind intensity and direction, taken at 30-minute intervals, between July $19^{\text {th }} 2001$ and June $14^{\text {th }} 2005$, were obtained from a station operated by the Brazilian Navy on the Abrolhos Archipelago $\left(17^{\circ} 57.85^{\prime} \mathrm{S}, 038^{\circ} 41.63^{\prime} \mathrm{W}\right)$. Frequencies of strong winds from different directions were calculated during the periods of immersion of the sediment traps for each reef. Northeasterly-easterly winds were considered those coming from directions between $0^{\circ}$ zero $\left.=\mathrm{N}\right)$ and $135^{\circ}$. Similarly, southerly winds were considered those coming from directions between $135^{\circ}$ and $225^{\circ}$.

\section{Corals and Zoanthids Cover}

Two or three stations were surveyed at each reef site. At each station, eight point-intercept transects (SEGAL; CASTRO, 2001) were sampled, except for a single station with six transects. Transects were $10 \mathrm{~m}$ long, with 250 randomly placed points marked on each line. The transect lines on each station lay parallel, some $40 \mathrm{~cm}$ from each other. During sampling, corals (scleractinians and milleporids) were identified to species level. Among zoanthids, only Palythoa caribaeorum was identified at species level. Other biotic categories were grouped as "others". Points over "hole" or "sediment" were not considered for calculating each category's cover, as they could not be properly sampled and/or because they were not suitable for the presence of reef corals. Such categories were eliminated from further analyses.

\section{Statistical Analyses}

Species composition and abundance were compared among sites and stations using cluster analysis and multi-dimensional scaling (MDS). The average similarity within clusters and the average dissimilarities between clusters, as well as the categories which better explain them, were determined through similarity percentages (SIMPER). All 
analyses used similarity matrices based on the BrayCurtis coefficient, with the aid of PRIMER 4.0 (Plymouth Marine Laboratory) (CLARKE; WARWICK, 1994). Cover data was log transformed (see UNDERWOOD, 1997). Other parameters were compared using ANOVAs followed by Tukey's HSD tests for unequal sample sizes (SPJOTVOLL; STOLINE, 1973) to verify if there were significant differences among sites. Pearson's $r$ (for normal data) or Spearman's rank (for non-normal data) was used to test correlations between variables. T-tests compared carbonate contents between sampling periods. All tests used a significance level of $\mathrm{p}<0.05$. Preliminarily, Shapiro-Wilks' normality test (ZAR, 1999) and Levene's test (BROWN; FORSYTHE, 1974) for homogeneity of variances were used on each data set. When necessary, data sets were square root, log, or arcsin transformed depending on the type of data (ZAR, 1999).

\section{Results \\ Sediment Deposition}

Sediment deposition peaks usually occurred between August and December. Maximum rates varied at different sites and different periods from near zero to $233 \mathrm{mg} \mathrm{cm}^{-2} \mathrm{day}^{-1}$ (Fig. 2). The yearly average sedimentation varied more than 10 -fold among sites, from 9 to $104 \mathrm{mg} \mathrm{cm}^{-2} \mathrm{day}^{-1}$. Due to a large number of outliers on Coroa Vermelha, when compared with traps from other sites, and due to the distinct physical setting (in a channel) of this site, we ran a correlation test (Pearson's r) to verify the influence of depth and distance from the channel in the sediment deposited in the traps. There was no correlation between either deposition and depth or deposition and distance from the channel in Coroa Vermelha with data from October-November/2001.

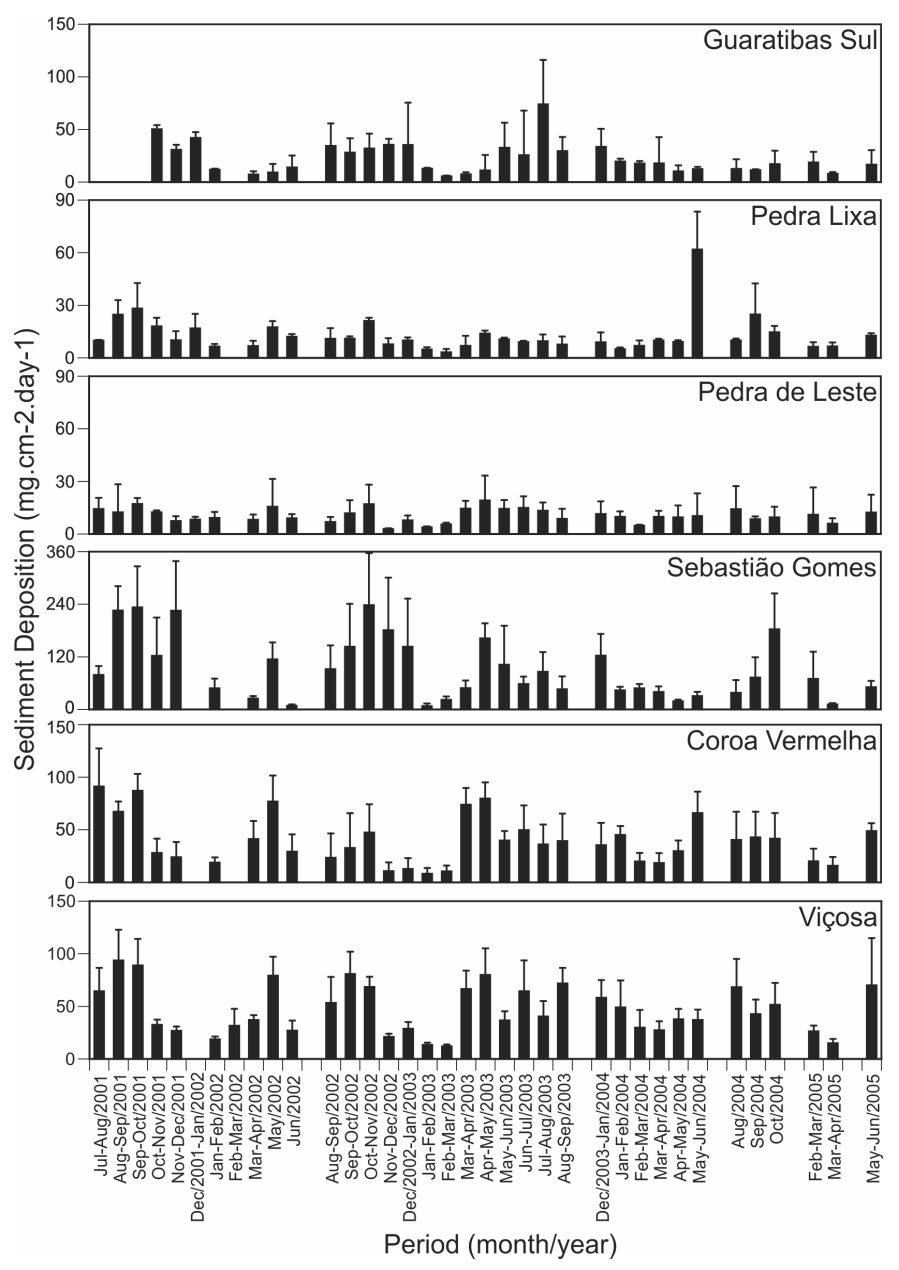

Fig. 2. Mean sediment deposition rates at the Abrolhos inner reefs, between July-August/2001 and May-June/2005. 
Sediment Carbonate Content

Carbonate contribution to the deposited sediments varied from c. 38\% (Guaratibas in OctoberNovember/2001) to c. $90 \%$ (Sebastião Gomes in October-November/2001) (Table 1). Two areas presented significant differences between OctoberNovember/2001 and February-March/2002: Pedra de Leste $(\mathrm{t}=2.9052$, d.f. $=10, \mathrm{p}=0.016)$ and Sebastião Gomes $(\mathrm{t}=-2.7172$, d.f. $=10, \mathrm{p}=0.022)$.

Carbonate data showed significantly different situations in October-November/2001 (ANOVA, d.f. $=29, \mathrm{p}=0.0125 \times 10^{-10}$ ) and FebruaryMarch/2002 (ANOVA, d.f. $=31, \mathrm{p}=0.00568 \times 10^{-13}$ ). In October-November/2001, post-hoc tests indicated a higher level of carbonate on Sebastião Gomes, an intermediate level on Pedra Lixa, and lower levels at other reef stations (Tukey for all significant tests, $\mathrm{p}<$ 0.002). Post-hoc tests indicated that samples from February-March/2002 had higher levels of carbonate on Pedra Lixa and Sebastião Gomes, intermediate levels on Pedra de Leste, and lower levels on Guaratibas, Coroa Vermelha, and Viçosa (Tukey for all significant tests, $\mathrm{p}<0.003$ ).

\section{Wind}

Wind frequency and speed data (Fig. 3) showed a predominance of northeasterly-easterly (NEE) winds over southern (S) winds during most of the sampling period. The highest frequencies of NE-E winds occurred during spring and summer. Average NE-E wind speeds were more constant throughout the year than $\mathrm{S}$ winds. Southerly winds, which are associated with cold fronts, affect the region for short periods (a few days at most). The periods with highest frequency of strong $\mathrm{S}$ winds occurred during autumn and winter. Also, monthly average and peak speeds of $S$ winds varied more than the average speeds of NE-E winds, as shown by their standard deviations.

Sediment and Wind Correlations

Sediment deposition presented a significant site-specific correlation, according to the differing wind conditions (Table 2).

\section{Corals and Zoanthids Cover}

Cluster analysis among benthic communities (scleractinians, milleporids, and zoanthids) showed that communities were fairly similar (Fig. 4). We considered the occurrence of three clusters, with a cutoff line at $70 \%$ similarity. The first cluster (\# 1) included only the three stations on Pedra Lixa, with a total average similarity of $53.24 \%$ (SIMPER). This cluster's stations presented the highest cover of Scleractinia and almost total absence of Milleporidae (Table 3). The second cluster (\# 2) included only two stations, both on Pedra de Leste (SIMPER average similarity $=76.64 \%$ ). Stations in this cluster had an intermediate cover of scleractinian corals and the highest cover of milleporids. They also had a relatively low cover of $P$. caribaeorum.

The remaining stations formed a single cluster (\# 3), including all the stations on Guaratibas, Sebastião Gomes, Coroa Vermelha, Viçosa, and the remaining station on Pedra de Leste (Le3). The average similarity between stations in Cluster 3 was high (SIMPER $=68.77 \%$ ), with stations characterized by a high cover of $P$. caribaeorum (Table 3 ).

Table 1. Percentage (mean \pm standard deviation) of calcium carbonate in sediments deposited on the Abrolhos inner reefs, Brazil, and sediment trap depth range in each station. Number of samples are indicated in parenthesis.

\begin{tabular}{lccc}
\hline & Nov 01 & Feb-Mar 02 & Sediment trap depth range (m) \\
\hline Guaratibas & $38.08 \pm 3.69(6)$ & $41.64 \pm 2.69(6)$ & $0.2-1.7$ \\
Pedra Lixa & $71.65 \pm 7.36(6)$ & $75.16 \pm 1,80(4)$ & $1.3-2.8$ \\
Pedra de Leste & $49.71 \pm 8.54(6)$ & $60.85 \pm 3.90(6)$ & $1.9-2.9$ \\
Sebastião Gomes & $89.82 \pm 9.06(6)$ & $76.42 \pm 8.00(6)$ & $1.0-2.0$ \\
Coroa Vermelha & $46.20 \pm 5.69(5)$ & $45.36 \pm 2.32(6)$ & $1.2-2.7$ \\
Viçosa & $43.23 \pm 7.53(6)$ & $47.29 \pm 4.23(9)$ & $0.8-2.8$ \\
\hline
\end{tabular}




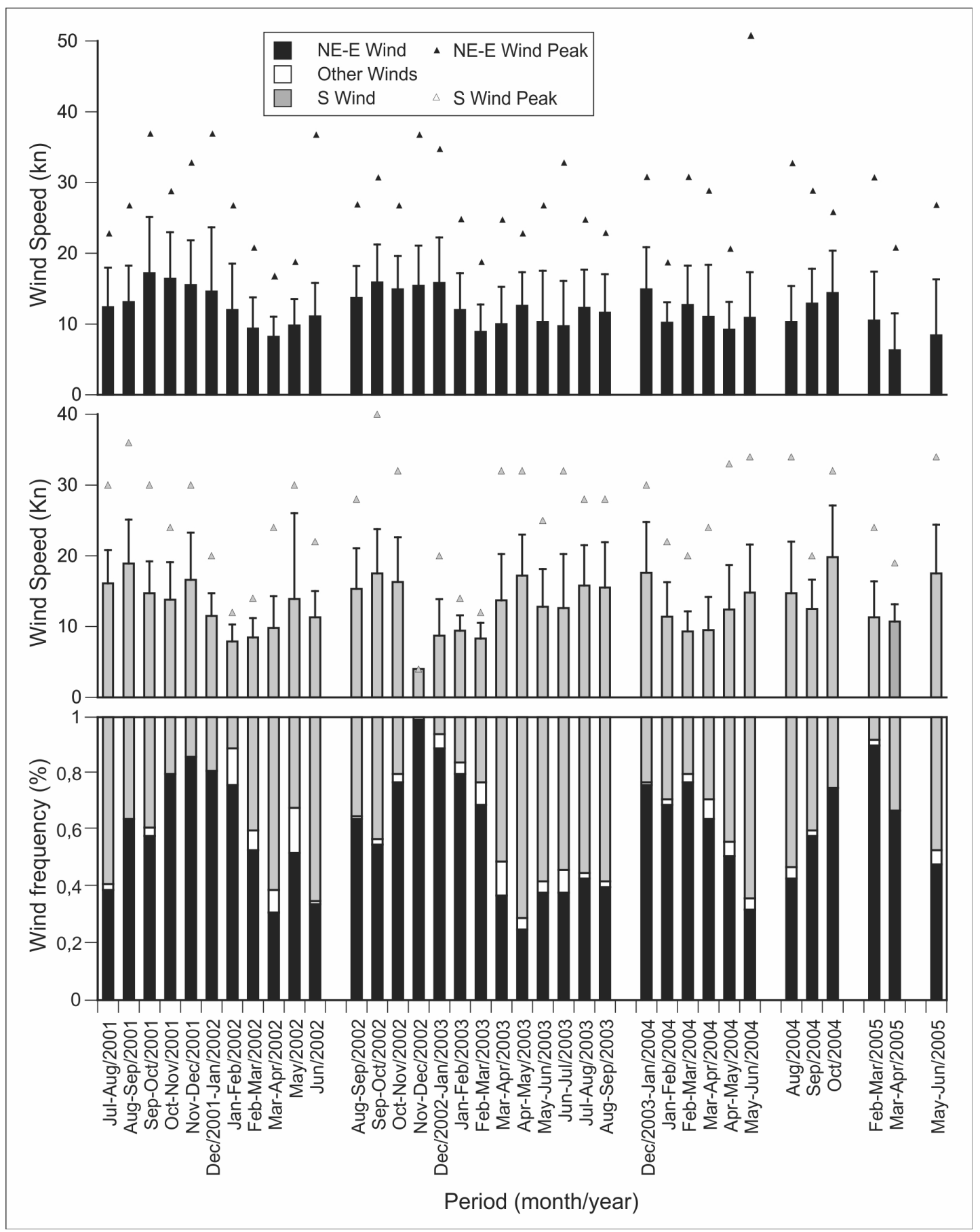

Fig. 3. Peak and mean monthly speeds of winds in the studied area, between July-August/2001 and May-June/2005. 
Table 2. Correlation between mean sediment deposition rates and wind periods of different directions, at the inner arc reefs of the Abrolhos Bank, Brazil. Correlations with Pedra Lixa and peak southern wind speed used Spearman's rank correlation $\left(r_{s}\right)$; all others used Pearson's correlation $(r)$. NS $=$ not significant. Notation $=r$ or $r_{s}(\mathrm{p})$.

\begin{tabular}{|c|c|c|c|c|c|c|}
\hline \multirow[t]{2}{*}{ Reefs } & \multicolumn{3}{|l|}{ NE-E Winds } & \multicolumn{3}{|l|}{ S Winds } \\
\hline & Frequency & Average Speed & Peak Speed & Frequency & Average Speed & Peak Speed \\
\hline Guaratibas & NS & $0.559(0.0005)$ & NS & NS & NS & NS \\
\hline Pedra Lixa & NS & $0.336(0.0390)$ & NS & NS & $0.446(0.0050)$ & $0.455(0.0041)$ \\
\hline Pedra de Leste & $-0.480(\mathrm{p}=0.0023)$ & NS & NS & $0.488(0.0019)$ & $0.531(0.0006)$ & $0.610(<0.0001)$ \\
\hline Sebastião Gomes & NS & $0.650(<0.0001)$ & NS & NS & $0.354(0.0310)$ & NS \\
\hline Coroa Vermelha & $-0.537(0.001)$ & NS & NS & $0.547(<0.0001)$ & $0.407 \quad(0.012)$ & $0.576(0.0002)$ \\
\hline Viçosa & $-0.374(0.0227)$ & NS & NS & $0.417(0.0102)$ & $0.5633(0.0003)$ & $0.675(<0.0001)$ \\
\hline
\end{tabular}

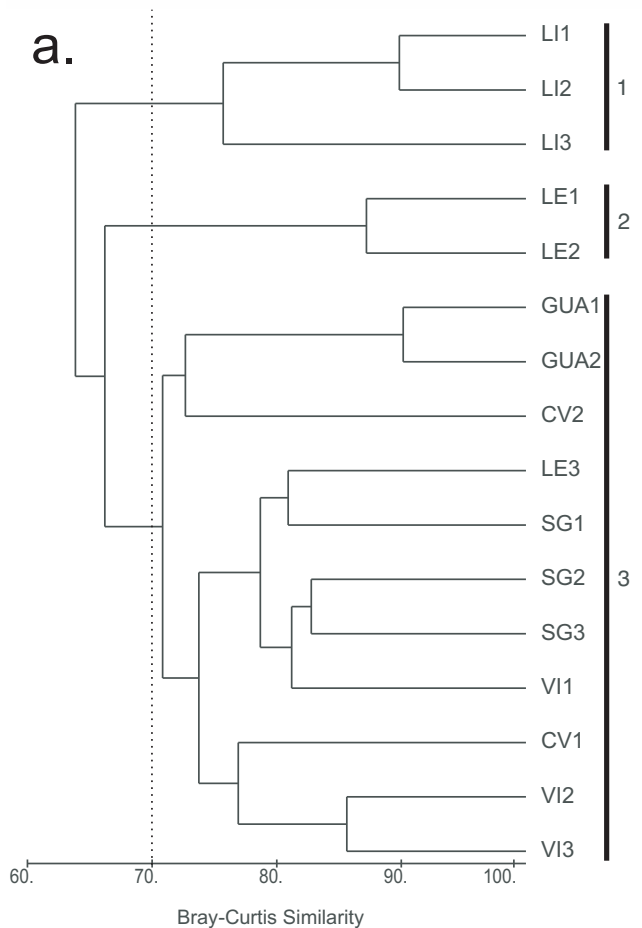

Fig. 4. Similarity among stations and sites of the Abrolhos inner reefs: analysis including scleractinians, hydrocorals, and zoanthids. a. Cluster analysis; $\mathrm{b}$. - MDS. Notation $=\mathrm{XN}$, where $\mathrm{X}=$ site and $\mathrm{N}=$ station within site; $\mathrm{C}=$ Coroa Vermelha, $\mathrm{G}=$ Guaratibas, $\mathrm{Le}=$ Pedra de Leste, $\mathrm{Li}=$ Pedra Lixa, $\mathrm{S}=$ Sebastião Gomes, V = Viçosa; Numbers besides vertical bars near the dendrogram indicate name of cluster as used in the text. Area of gray circles are equivalent to yearly mean sediment deposition of each station.

b.

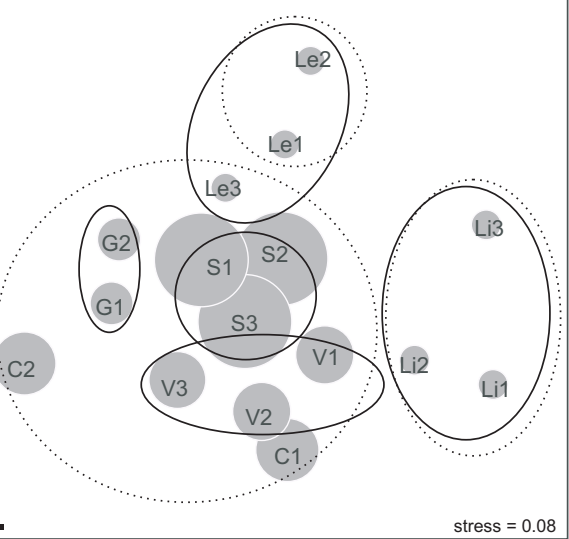


Table 3. Benthic cover (mean \pm standard deviation) by sampled station on inner reefs of the Abrolhos Bank, Brazil.

\begin{tabular}{|c|c|c|c|c|c|c|c|c|}
\hline Reef & Guaratibas & Guaratibas & Pedra Lixa & Pedra Lixa & Pedra Lixa & Pedra de Leste & Pedra de Leste & Pedra de Leste \\
\hline Station & G1 & G2 & Lil & Li2 & $\mathrm{Li} 3$ & Lel & Le2 & Le3 \\
\hline Corals & $6.51 \pm 3.04$ & $6.87 \pm 3.45$ & $16.26 \pm 5.09$ & $13.86 \pm 2.44$ & $18.79 \pm 3.74$ & $16.00 \pm 5.61$ & $16.22 \pm 4.21$ & $7.50 \pm 3.28$ \\
\hline Scleractinia & $2.43 \pm 1.70$ & $2.58 \pm 2.15$ & $16.26 \pm 5.09$ & $13.86 \pm 2.44$ & $18.41 \pm 3.69$ & $7.40 \pm 2.85$ & $9.17 \pm 1.73$ & $4.36 \pm 2.83$ \\
\hline Milleporidae & $4.08 \pm 3.31$ & $4.29 \pm 4.32$ & 0 & 0 & $0.38 \pm 0.81$ & $8.59 \pm 5.65$ & $7.05 \pm 3.71$ & $3.14 \pm 1.84$ \\
\hline Zoanthidae & $6.51 \pm 11.75$ & $41.43 \pm 6.85$ & $2.67 \pm 4.99$ & $8.72 \pm 2.43$ & $1.12 \pm 2.16$ & $3.72 \pm 3.00$ & $0.62 \pm 0.49$ & $19.22 \pm 2.44$ \\
\hline Agaricia humilis & $0.10 \pm 0.29$ & $0.10 \pm 0.29$ & $0.30 \pm 0.47$ & $0.43 \pm 0.31$ & $0.58 \pm 0.51$ & $1.15 \pm 0.97$ & $0.57 \pm 0.58$ & $0.50 \pm 0.55$ \\
\hline Favia gravida & $0.41 \pm 0.53$ & $0.21 \pm 0.22$ & $1.07 \pm 0.90$ & $0.99 \pm 0.50$ & $0.80 \pm 0.77$ & $0.79 \pm 0.48$ & $0.47 \pm 0.27$ & $0.55 \pm 0.42$ \\
\hline Madracis decactis & 0 & 0 & 0 & 0 & 0 & $0.17 \pm 0.47$ & $0.52 \pm 1.48$ & 0 \\
\hline Meandrina braziliensis & 0 & 0 & 0 & 0 & $0.10 \pm 0.19$ & 0 & 0 & 0 \\
\hline Montastrea cavernosa & 0 & $0.48 \pm 1.37$ & 0 & 0 & $5.51 \pm 3.21$ & $0.95 \pm 0.86$ & $1.92 \pm 0.96$ & $0.56 \pm 0.85$ \\
\hline Mussismilia braziliensis & $0.53 \pm 0.80$ & $0.25 \pm 0.57$ & $11.99 \pm 4.72$ & $8.30 \pm 2.06$ & $3.13 \pm 1.73$ & $1.46 \pm 2.60$ & $1.44 \pm 1.40$ & $1.28 \pm 1.45$ \\
\hline Mussismilia harttii & $0.20 \pm 0.58$ & 0 & 0 & $0.17 \pm 0.48$ & $1.10 \pm 0.99$ & $1.23 \pm 1.55$ & $1.65 \pm 1.33$ & $0.70 \pm 0.87$ \\
\hline Mussismilia hispida & $0.30 \pm 0.85$ & $0.35 \pm 0.59$ & 0 & $0.11 \pm 0.32$ & $0.74 \pm 0.58$ & $0.62 \pm 1.04$ & $0.93 \pm 0.67$ & $0.56 \pm 0.76$ \\
\hline Porites astreoides & 0 & 0 & $0.10 \pm 0.19$ & $0.34 \pm 0.39$ & $0.11 \pm 0.21$ & $0.10 \pm 0.29$ & $0.16 \pm 0.46$ & 0 \\
\hline Porites branneri & $0.20 \pm 0.31$ & $0.22 \pm 0.35$ & $0.05 \pm 0.14$ & $0.06 \pm 0.16$ & $0.05 \pm 0.14$ & $0.21 \pm 0.31$ & $0.10 \pm 0.19$ & $0.10 \pm 0.19$ \\
\hline Scolymia wellsii & 0 & 0 & 0 & 0 & $0.05 \pm 0.15$ & 0 & 0 & 0 \\
\hline Siderastrea spp. & $0.68 \pm 1.11$ & $0.96 \pm 1.40$ & $2.75 \pm 1.45$ & $3.47 \pm 1.96$ & $6.23 \pm 1.70$ & $0.73 \pm 0.53$ & $1.41 \pm 1.26$ & $0.10 \pm 0.19$ \\
\hline Millepora alcicornis & $4.08 \pm 3.31$ & $4.29 \pm 4.32$ & 0 & 0 & $0.38 \pm 0.81$ & $5.37 \pm 5.03$ & $4.44 \pm 3.82$ & $1.27 \pm 2.03$ \\
\hline Millepora nitida & 0 & 0 & 0 & 0 & 0 & $3.23 \pm 2.18$ & $2.62 \pm 2.61$ & $1.87 \pm 0.95$ \\
\hline Palythoa caribaeorum & $55.90 \pm 11.36$ & $40.13 \pm 6.54$ & $2.57 \pm 4.89$ & $8.36 \pm 2.34$ & $1.12 \pm 2.16$ & $2.82 \pm 3.16$ & $0.05 \pm 0.14$ & $18.61 \pm 2.71$ \\
\hline Zoanthus spp. & $2.68 \pm 1.84$ & $1.30 \pm 0.67$ & $0.10 \pm 0.19$ & $0.37 \pm 0.60$ & 0 & $0.90 \pm 0.74$ & $0.57 \pm 0.44$ & $0.61 \pm 0.48$ \\
\hline Reef & Sebastião Gome & s Sebastião Gome & s Sebastião Gomes & s Coroa Vermelha & Coroa Vermelha & Viçosa & Viçosa & Viçosa \\
\hline Station & S1 & S2 & \$3 & $\mathrm{C} 1$ & $\mathrm{C} 2$ & V1 & V2 & V3 \\
\hline Corals & $11.85 \pm 3.96$ & $11.74 \pm 2.62$ & $13.50 \pm 3.66$ & $5.09 \pm 3.22$ & $14.67 \pm 6.89$ & $9.90 \pm 4.84$ & $13.80 \pm 8.76$ & $11.78 \pm 3.60$ \\
\hline Scleractinia & $7.17 \pm 2.79$ & $5.32 \pm 1.64$ & $7.05 \pm 2.99$ & $5.09 \pm 3.22$ & $8.26 \pm 3.59$ & $6.55 \pm 3.83$ & $13.64 \pm 8.47$ & $10.86 \pm 3.65$ \\
\hline Milleporidae & $4.67 \pm 3.17$ & $6.42 \pm 2.74$ & $6.45 \pm 1.93$ & 0 & $6.41 \pm 4.05$ & $3.35 \pm 3.75$ & $0.17 \pm 0.47$ & $0.92 \pm 1.31$ \\
\hline Zoanthidae & $47.64 \pm 9.04$ & $17.44 \pm 12.65$ & $33.72 \pm 19.37$ & $40.10 \pm 27.48$ & $59.61 \pm 10.39$ & $24.06 \pm 20.47$ & $34.98 \pm 18.24$ & $51.73 \pm 15.33$ \\
\hline Agaricia humilis & $0.40 \pm 0.68$ & $0.11 \pm 0.21$ & $0.44 \pm 0.47$ & $0.25 \pm 0.37$ & $2.52 \pm 1.12$ & $0.27 \pm 0.34$ & $0.83 \pm 0.70$ & $0.84 \pm 0.59$ \\
\hline Favia gravida & $0.56 \pm 0.50$ & $0.73 \pm 0.92$ & $1.19 \pm 0.49$ & $0.85 \pm 0.58$ & $0.87 \pm 0.98$ & $0.89 \pm 0.69$ & $2.07 \pm 1.02$ & $1.23 \pm 0.81$ \\
\hline Madracis decactis & 0 & 0 & $0.05 \pm 0.15$ & 0 & 0 & 0 & 0 & 0 \\
\hline Meandrina braziliensis & 0 & 0 & 0 & 0 & 0 & 0 & 0 & 0 \\
\hline Montastrea cavernosa & $1.95 \pm 2.56$ & $0.05 \pm 0.15$ & 0 & $0.09 \pm 0.27$ & $0.20 \pm 0.56$ & $0.28 \pm 0.54$ & $0.36 \pm 0.85$ & 0 \\
\hline Mussismilia braziliensis & $1.89 \pm 1.90$ & $1.65 \pm 1.25$ & $3.68 \pm 3.14$ & $2.77 \pm 2.81$ & 0 & $3.26 \pm 2.76$ & $6.27 \pm 6.29$ & $3.42 \pm 3.15$ \\
\hline Mussismilia harttii & $0.75 \pm 0.87$ & $1.19 \pm 1.10$ & $0.11 \pm 0.30$ & $0.47 \pm 1.19$ & $4.35 \pm 3.53$ & $0.23 \pm 0.49$ & $1.85 \pm 1.62$ & $3.71 \pm 2.66$ \\
\hline Mussismilia hispida & $0.20 \pm 0.34$ & $0.31 \pm 0.29$ & $0.43 \pm 0.47$ & $0.10 \pm 0.29$ & 0 & 0 & $0.25 \pm 0.71$ & $0.21 \pm 0.32$ \\
\hline Porites astreoides & $0.14 \pm 0.21$ & $0.27 \pm 0.38$ & $0.58 \pm 0.96$ & $0.28 \pm 0.66$ & $0.05 \pm 0.14$ & $0.28 \pm 0.34$ & $0.68 \pm 0.84$ & $0.30 \pm 0.70$ \\
\hline Porites branneri & $0.28 \pm 0.34$ & $0.26 \pm 0.30$ & $0.17 \pm 0.23$ & 0 & $0.21 \pm 0.22$ & $0.11 \pm 0.21$ & 0 & 0 \\
\hline Scolymia wellsii & 0 & 0 & 0 & 0 & 0 & 0 & 0 & 0 \\
\hline Siderastrea spp. & $1.02 \pm 1.02$ & $0.75 \pm 0.52$ & $0.41 \pm 0.50$ & $0.25 \pm 0.48$ & $0.05 \pm 0.15$ & $1.23 \pm 1.65$ & $1.33 \pm 0.86$ & $1.15 \pm 1.82$ \\
\hline Millepora alcicornis & $0.49 \pm 0.77$ & $1.76 \pm 2.12$ & $1.25 \pm 1.35$ & 0 & $4.03 \pm 2.75$ & $0.29 \pm 0.65$ & $0.17 \pm 0.47$ & $0.92 \pm 1.31$ \\
\hline Millepora nitida & $4.18 \pm 2.61$ & $4.66 \pm 1.94$ & $5.20 \pm 2.41$ & 0 & $2.39 \pm 1.89$ & $3.06 \pm 3.67$ & 0 & 0 \\
\hline Palythoa caribaeorum & $46.54 \pm 8.77$ & $17.38 \pm 12.55$ & $31.15 \pm 18.84$ & $34.06 \pm 29.36$ & $55.27 \pm 12.02$ & $24.01 \pm 20.54$ & $28.72 \pm 16.64$ & $49.85 \pm 17.05$ \\
\hline Zoanthus spp. & $1.10 \pm 0.88$ & $0.05 \pm 0.15$ & $2.57 \pm 1.29$ & $6.04 \pm 4.48$ & $4.34 \pm 2.47$ & $0.05 \pm 0.15$ & $6.27 \pm 4.07$ & $1.88 \pm 2.09$ \\
\hline
\end{tabular}

Due to the exceptional cover of Palythoa caribaeorum at most stations and its corresponding influence in the formation of the clusters, another cluster analysis was undertaken, excluding the zoanthids (Fig. 5). This analysis defined two main clusters, apart from a single isolated station (Coroa Vermelha channel station C2; see Table 3).

A cluster without zoanthids (Fig. 5; cluster A), with stations on Pedra de Leste, Sebastião Gomes, and Guaratibas (SIMPER average similarity $=57.29 \%$ ), was characterized mainly by the high coverage of milleporids and a low cover of Mussismilia braziliensis. This cluster presented a secondary grouping near the $70 \%$ line, separating the Guaratibas stations from the others (see Fig. 5). These secondary groups differed (SIMPER average dissimilarity = $63.21 \%$ ) mainly by a higher contribution of scleractinians at stations on Pedra de Leste-Sebastião Gomes and a higher contribution of milleporids (with M. nitida absent) to the total cover at stations on Guaratibas (Table 3).

Another cluster without zoanthids (Fig. 5; cluster B) included all the stations on Pedra Lixa, Viçosa, and the reef crest station on Coroa Vermelha (C1). These stations (SIMPER average similarity = $53.74 \%$ ) showed a relatively high cover of Mussismilia braziliensis (SIMPER $=$ this species explained $53.78 \%$ of the total cluster similarity). These 
stations usually did not present Millepora nitida (except for $\mathrm{V} 1=3.23 \%$ ).

Stations at each site (except Coroa Vermelha), appeared close set in MDS diagrams and

a.

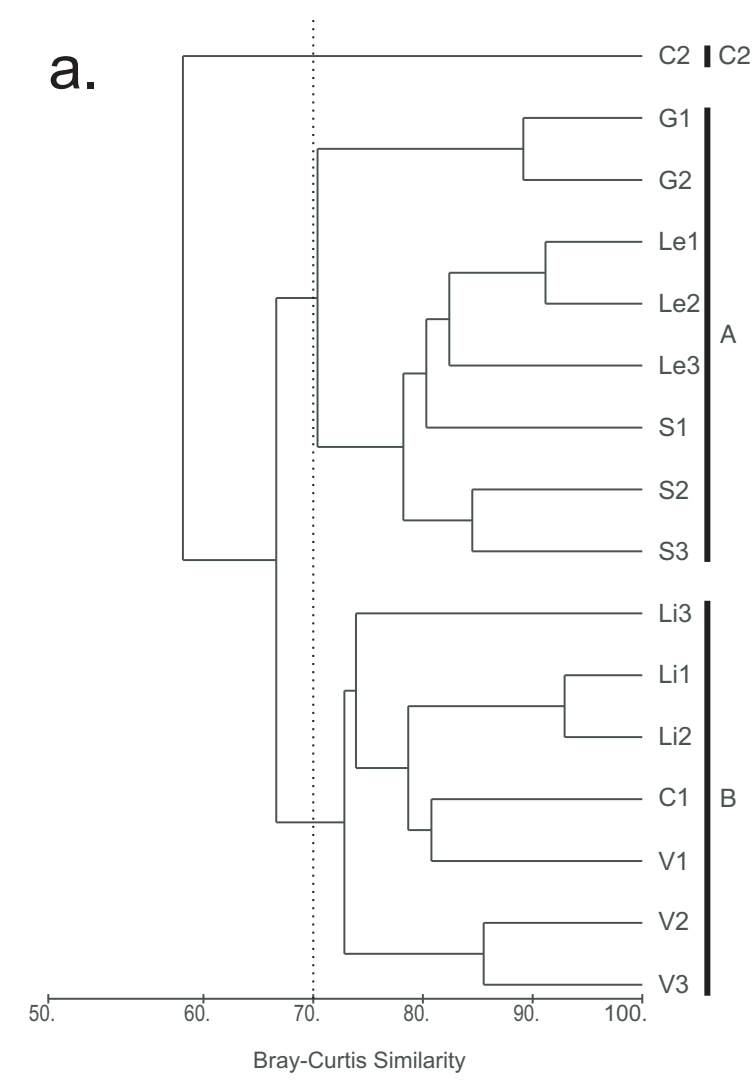

occupying spaces without intersections with other sites (continuous lines in Figs $4 \mathrm{~b}$ and $5 \mathrm{~b}$ ). This suggests that each site had particular benthic communities.

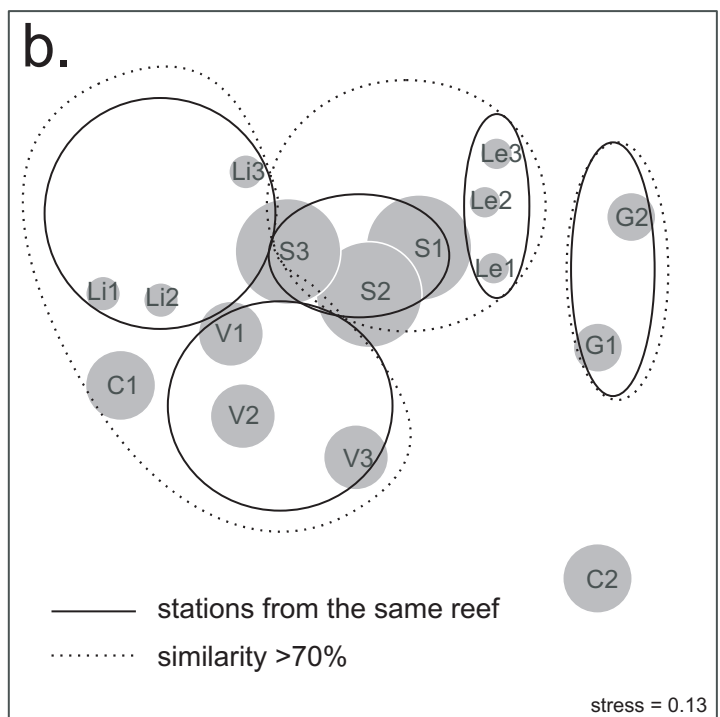

Fig. 5. Similarity among stations and sites of the Abrolhos inner reefs: analysis including scleractinians and hydrocorals. a. - Cluster analysis; b. - Multidimentional scaling (MDS). Notation $=\mathrm{XN}$, where $\mathrm{X}=$ site and $\mathrm{N}=$ station within; $\mathrm{C}=$ Coroa Vermelha, $\mathrm{G}=$ Guaratibas, $\mathrm{Le}=$ Pedra de Leste, $\mathrm{Li}=$ Pedra Lixa, $\mathrm{S}=$ Sebastião Gomes, $\mathrm{V}=$ Viçosa; Letters besides vertical bars near the dendrogram indicate name of cluster as used in the text. Area of gray circles are equivalent to yearly mean sediment deposition of each station. 
The only significant Pearson's correlation among biotic and/or abiotic parameters indicated that total coral cover (Scleractinia + Milleporidae) was negatively correlated with the cover of Palythoa caribaeorum $(\mathrm{r}=-0.8978, \mathrm{p}=0.015)$. No significant correlation was found between sediment variables and benthic communities. However, plotting yearly mean sediment deposition on an MDS plot showed a strong tendency towards a large cover of Palythoa caribaeorum in areas of high deposition (Fig. 4).

\section{Discussion}

Sediment deposition rates at the study sites showed two main phenomena with which coral communities must deal: 1) rates are extremely variable among inner reefs; 2) average monthly rates may present strong seasonality, with yearly peak rates four to 26 times higher than yearly minima at the same site. Data on terrigenous sediment input in the area are scarce (DUTRA et al., 2006; SEGAL et al., 2008). However, there is evidence to suggest that the carbonate fraction is produced locally. According to Leão et al. (2006), sediments in the coastal area have 30 to $70 \%$ of siliciclastics, while very close to the reefs the terrigenous contribution to the sediment composition can be less than $10 \%$, due to the material originating on the reef. The main sources of the siliciclastic fraction of sediment around the reefs are reworked sediment of Tertiary age originating from the erosion of the Barreiras Group and river loads transported to the reef area by longshore currents (LEÃO; GINSBURG, 1997). The Barreiras Group covers most of the hinterland and outcrops between $4^{\circ}$ and $20^{\circ} \mathrm{S}$ (KNOPPERS et al., 2002). Terrigenous sediment on the Abrolhos Bank can, thus, originate from rivers to the north (LEÃO; GINSBURG, 1997) and/or south of the area (SUMMERHAYES et al., 1976). Sediment plumes from major rivers to the north and south of Abrolhos seasonally reach this bank (SEGAL et al., 2008). These different geographical sources are associated with varying longshore drifts, which run southwards to the north of Baleia Point and northwards south of it (BITTENCOURT et al., 2000). More particularly, the plume of Doce River runs northwards and that of Jequitinhonha River runs southwards, at least in the autumn (SUMMERHAYES et al., 1976). A non-local main source of terrigenous sediment is referred to by Knoppers et al. (1999) who indicate (at least for the summer) a secondary role for the Caravelas River estuarine complex as a sediment source, when compared with material resuspended from sediment banks near the coast. Indeed, the water flow in the channel between the reefs and the coast constitutes a hydraulic barrier that inhibits the exchange of particles between the coastal and the more turbid waters of the channel and the remaining reefs of the platform (LESSA; CIRANO, 2004).

Radiometric signatures from sediments from Pedra de Leste $\left(17^{\circ} 47.261^{\prime} \mathrm{S}, 039^{\circ} 02.795^{\prime} \mathrm{W}\right)$ show small seasonal variation (SEGAL et al., 2008). Most sites in our study did not show changes in sediment carbonate content from different periods, usually with more than $50 \%$ of non-carbonatic sediment deposition, except for those bordering the Suest Channel (Pedra de Leste and Sebastião Gomens) (Table 1). These data and temporal series of images show continuous sediment plumes reaching the area (SEGAL et al., 2008), suggesting that Abrolhos inner reefs are under the almost continuous influence of a large load of nonbiogenic suspended sediment.

Sites that presented seasonal variation in carbonate composition (Pedra de Leste and Sebastião Gomes) are located on opposite sides of the Sueste Channel (which runs roughly between Parcel das Paredes and the mainland, and continues between the Parcel das Paredes and Sebastião Gomes reefs). Variation at these sites had opposite trends, with carbonates rising in October-November/2001 (wind frequency: $80 \%$ NE; $20 \%$ S) on Sebastião Gomes and in February-March/2002 (wind frequency: 53\% NE; $40 \%$ S) on Pedra de Leste. In both cases, carbonates rise under wind conditions that generate sediments (depths off the sites are greater than $10 \mathrm{~m}$ ).

Sebastião Gomes presented the largest sediment deposition and the largest carbonate composition among all the stations. It is, therefore, probable that sediments came from different sources in each sampling period. OctoberNovember/2001 presented mostly northeasterly winds, a higher carbonate contribution (c. 90\%) and high deposition rates $\left(122-225 \mathrm{mg} \mathrm{cm}^{-2}\right.$ day $\left.^{-1}\right)$, while March/2002 had a higher incidence of southerly winds, a lower carbonate contribution $(c .75 \%)$ and lower deposition rates $\left(24-25 \mathrm{mg} \mathrm{cm}^{-2}\right.$ day $\left.^{-1}\right)$. It must be noted that this "lower" deposition rate approximates to those of Coroa Vermelha and Viçosa under southerly winds. Therefore, as on Pedra de Leste, the carbonate contribution rises under wind conditions that generate waves that strike the reef's margins strongly and directly. This suggests a local origin for the sediments, which is probably resuspended from the adjoining reef front and/or eroded along the sides of spurs; such sediments may be trapped deeper in the grooves (WOOD; OPPENHEIMER, 2000). The difference in sedimentation rates between these sites may be explained by the vertical drop of the reef margin of Pedra de Leste and the presence of a wider shallow reef front on Sebastião Gomes. Reefs' bases (where unconsolidated sediments begin) at these sites represent the shallowest (Sebastião Gomes - highest 
sedimentation) and deepest (Pedra de Leste - smallest sedimentation) among all the sampled sites.

The close association between wind and sediment deposition (Table 2) indicates that resuspension must be a major factor in the dynamics of the sediments in the area. Larcombe et al. (2001) reported a situation where waves create turbidity by resuspending sediment. They observed an inverse association between turbidity and sediment deposition as wave energy decreased at the bottom. Particle transport on the reef occurs in the leeward direction (DODGE et al., 1974; Hammer; Wolanski, 1988 apud KNOPPERS et al., 1999; Jones, 1995 apud KNOPPERS et al., 1999). Sediment resuspended by waves deposits when turbulence decreases in more protected areas. Turbidity events due to resuspension and subsequent deposition were seen to occur at short time spans (i.e. a couple of hours), usually during one tidal cycle (LARCOMBE et al., 2001). Erosion processes increase significantly when the crests of the reefs studied become exposed during low tides (LEÃO et al., 1985; LEÃO et al., 1988), generating carbonate particles. This explains the relatively high carbonate content when compared with the bottom sediment adjacent to the reefs (LEÃO et al., 2006).

Sediment deposition rates are related to wind/wave direction (MUZUKA et al., 2010), site positioning on the reef (windward or leeward to a particular wind), reef morphology, and reef site surroundings (STORLAZZI et al., 2009). The positive correlation of sediment deposition at Guaratibas station with average northeasterly winds (Table 2) is possibly a result of sediments resuspended on the windward side traveling over or through the sides of the reef and depositing on the more sheltered (and with lower hydrodynamics) leeward side. Pedra Lixa presented low depositions, correlated with average wind speed and southerly wind peak speed (Table 2). This situation may be associated with the site's being surrounded by reef structures on all sides, with only a nearby source of sediment; sediments suspended at a distance would not be carried to the area. The relatively high carbonate content would support this assumption (Table 1). Pedra de Leste, Coroa Vermelha, and Viçosa stations presented similar correlations of sediment deposition, positive with southerly and negative with northeasterly winds (Table 2). As Pedra de Leste presents much lower deposition rates than do Coroa Vermelha and Viçosa, the arriving sediment must come mainly from nearby areas. Such lower depositions are related to site positioning and surroundings. Pedra de Leste is located on the southeastern side of a large bank (more than $10 \mathrm{~km}$ long and forming a wide barrier to the NE wind) and it is separated from small pinnacles close by to the south by depths in excess of $10 \mathrm{~m}$. Both structures protect it from the influence of northeasterly winds and from far-away sediment resuspended by southerly winds. Coroa Vermelha and Viçosa receive sediment resuspended or carried over the top of the reefs and deposited in the traps on the leeward side, as suggested for Guaratibas. Indeed, all stations with higher sedimentation (Coroa Vermelha, Viçosa and Sebastião Gomes) presented reef crests with sand banks windward (from positively correlated winds) of the station's position (see PRATES, 2006), suggesting a predominantly in-reef source of resuspended sediments. The negative correlation with northeasterly winds at Coroa Vermelha and Viçosa may be a reverse effect of such sediment dynamics, with sediment from sandy banks being pushed away from the traps. As explained before, Sebastião Gomes has a unique reef border morphology that may help accumulate sediments with northeasterly winds, explaining the observed positive correlation also under such conditions.

The analysis of coral communities and sedimentation (deposition and, consequently, turbidity) suggests an indirect relationship between them, through the cover of the zoanthid Palythoa caribaeorum. The association of this zoanthid with high sedimentation, although not mandatory (absence of significant correlation), is clearly seen in the MDS (Fig. 4b). It shows that stations with high sedimentation are clustered, their inner similarity being explained mainly by the high abundance of $P$. caribaeorum. Its abundance affects total coral cover, as shown by the negative significant correlation among corals and $P$. caribaeorum cover. Therefore, $P$. caribaeorum may be an agent for the indirect effect of sedimentation upon the community structure. Some characteristics of this species suggest that it is well adapted for high sedimentation environments. $P$. caribaeorum incorporates fine sediment particles in its tissues, in a proportion up to $45 \%$ of its wet weight, rejecting only the larger particles (HAYWICK; MUELLER, 1997). The great production of mucus and the smooth, continuous colonial surface, which produces less friction when compared with the coarse surface of the rest of the reef, would help remove sediment particles from the top of the colonies. Furthermore, $P$. caribaeorum has few predators (SUCHANEK; GREEN, 1981; SEBENS, 1982; STAMPAR et al. 2007; FRANCINI-FILHO; MOURA 2010), forms continuous covers and may fragment when exposed to physical disturbances, usually with fragments regenerating afterwards (ACOSTA et al., 2001). It is also competitively superior to other zoanthids (BASTIDAS; BONE, 1996) and to several corals, as Agaricia agaricites and Siderastrea siderea (see SUCHANEK; GREEN, 1981). On the other hand, although corals may even benefit from sediments, as in feeding on associated organic matter (MILLS; SEBENS, 1997; ANTHONY, 1999), they may also 
have to spend energy on sediment removal, depending on the load and other variables (LASKER, 1980; ROGERS, 1983; STAFFORD-SMITH; ORMOND, 1992). Corals may, therefore, be comparatively less competitive and/or successful than $P$. caribaeorum in high sedimentation habitats.

Each site's coral community, except that of Coroa Vermelha, seems to have unique characteristics. Stations at the same site appear relatively clustered in the MDS without zoanthids (Fig. 5). On the other hand, clusters were formed with a high level of similarity, indicating that the inner reefs do not have major differences among sites. This duality is to be explained by the variation in the dominant taxa at each site, especially due to a higher abundance of scleractinians in one group and milleporids in the other. However, our analysis did not show clusters (70\% level of similarity or higher) associated with geographical patterns or sediment deposition rates. Distributional patterns and/or dominance of each species occur in a mosaic, which can occur on a small scale, as shown by the great variation in species cover among stations from the same site (see Table 1). Coral communities at the study sites are relatively poor and may be structured by local events, on a small scale, or by stochastic events. Sebens (1982), regarding zoanthids, and Hughes (1989), regarding corals, suggested that abundance would be the result of historical events, competition and predation. Small scale and stochastic events can be different between and within reefs. Recovery processes after disturbances, together with other factors constantly in action, could be responsible for the different abundances among assemblages of the same species. The structure of communities under such influences would show distributions in mosaic, without clear geographical or zonation patterns, as occurred with our results.

In our study, several sites showed comparatively high deposition rates (see EDMUNDS; DAVIES, 1989; NZALI et al., 1998; LARCOMBE; WOOLFE, 1999; BARNES; LOUGH, 1999; LARCOMBE et al., 2001). Some studies related high sediment deposition rates with a decrease in coral diversity and abundance (ROGERS, 1990; RICE; HUNTER, 1992; RIEGL, 1995). On Brazilian reefs, Dutra et al. (2006) found a positive correlation between number of coral species and the presence of Millepora nitida $\mathrm{x}$ sediment deposition, although they also found a negative correlation between sediment deposition $\mathrm{x}$ average diameter of coral colonies. Based on the negative effect, these authors state that a "sediment accumulation rate of $10 \mathrm{mg} \mathrm{cm}^{-2}$ day" $^{-1}$ seems to constitute a critical limit for coral survival". However, our data did not lead to the same conclusion. Coral cover was not correlated with average or peak monthly sedimentation per site, indicating that these abiotic parameters alone do not necessarily imply a reduced coral cover. Moreover, we found coral communities (Table 3) living at sites with yearly average from 9 to $104 \mathrm{mg} \mathrm{cm}^{-2} \mathrm{day}^{-1}$ and annual peak monthly deposition from 17 to $233 \mathrm{mg} . \mathrm{cm}^{-2}$. day ${ }^{-1}$. The site with highest sediment deposition (Sebastião Gomes) had coral covers ranging from 11.7 to $13.5 \%$, similar to the best sites studied by Dutra et al. (2006).

Coral communities on the inner reefs of Abrolhos are subject to high sediment deposition and turbidity, which may have been present for several millennia, taking into account sea-level variation in the geological history of modern reefs (LEÃO et al., 1997). In recent terms (Holocene), there are indications that reefs to the north of Abrolhos would have been under high sedimentation for at least 3,000 years, due mainly to sea-level variations (LEÃO et al., 1997). The Abrolhos area has been subject to the same kind of variation (MARTIN et al., 1985), which has been bringing the reefs closer to shore over the last 5,000 years (LEÃO; GINSBURG, 1997). This regression probably was the main cause for the mixing of carbonatic and siliciclastic sediments on Abrolhos (LEÃO; GINSBURG, 1997).

It has been hypothesized that some coral reefs may have arisen in turbid environments (LARCOMBE; WOOLFE, 1999) and that reef coral origins may be associated with high sedimentation environments (POTTS; JACOBS, 2002). These hypotheses and descriptions of high coral cover in high sedimentation environments (LARCOMBE et al., 2001; ANTHONY; LARCOMBE, 2002) show that the influence of sedimentation on reef corals is not always direct or negative (see also MILLS; SEBENS, 1997; ANTHONY, 1999). Our results agree with such hypotheses, indicating that high sediment deposition by itself does not hinder the development of Brazilian coral reef communities.

\section{AcKNOWLEDGEMENTS}

We thank the following persons and institutions: M. Medeiros for his help with the illustrations; Aracruz Celulose and CEPEMAR, for the opportunity to acquire field data; the Brazilian Navy, Diretoria de Hidrografia e Navegação, Banco Nacional de Dados Oceanográficos, for wind data; G. Nunan and C. Zilberberg for their help with the final English version, and CNPq, FAPERJ, FUJB, and CAPES for grants and funds that helped in the elaboration of this study.

\section{REFERENCES}

ACOSTA, A.; SAMMARCO, P. W.; DUARTE, L. F. Asexual reproduction in zoanthid by fragmentation: the role of exogenous factors. Bull. Mar. Sci., v. 68, p. 363381, 2001. 
ANTHONY, K. R. N. Coral suspension feeding on fine particulate matter. J. expl mar. Biol. Ecol., v. 232, p. 85-106, 1999

ANTHONY, K. R. N. Enhanced energy status of corals on coastal, high turbidity reefs. Mar. Ecol. Prog. Ser., v. 319 , p. $111-116,2006$

ANTHONY, K. R. N.; LARCOMBE, P. Coral reefs in turbid waters: sediment-induced stresses in corals and likely mechanisms of adaptation. INTERNATIONAL CORAL REEF SYMPOSIUM, 9, 2002. Proceedings..., v. 1, p. 239-244, 2002.

BARNES, D. J.; LOUGH, J. M. Porites growth characteristics in a changed environment: Misima Island, Papua New Guinea. Coral Reefs, v. 18, p. 213-218, 1999.

BASTIDAS, C., BONE, D. Competitive strategies between Palythoa caribaeorum and Zoanthus sociatus (Cnidaria: Anthozoa) at a reef flat environment in Venezuela. Bull. Mar. Sci., v. 59, p. 543-555, 1996.

BITTENCOURT, A. C. S. P.; DOMINGUEZ, J. M. L.; MARTIN, L.; SILVA, I. R. Patterns of sediment dispersion coastwise the State of Bahia - Brazil. An. Acad. Bras. Ciênc., v. 72, 271-287, 2000.

BLOMQVIST, S., KOFOED, C. Sediment trapping - A subaquatic in situ experiment. Limnol. Oceanogr., v. 26, p. 585-590, 1981.

BROWN, B. E. Disturbances to reefs in recent times. In: BIRKELAND, C. (Ed.). Life and death of coral reefs. New York: Chapman and Hall, 1997. p. 354-379.

BROWN, M. B.; FORSYTHE, A. B. Robust Tests for the Equality of Variances. J. Amer. Stat. Assoc., v. 69, p. 364-367, 1974.

CLARKE, K. R., WARWICK, R. M. Change in marine communities: an approach to statistical analysis and interpretation. Plymouth: Plymouth Marine Laboratory, 1994. 246 p.

CORTÉS, J.; RISK, M. J. A reef under siltation stress Cahuita, Costa Rica. Bull. Mar. Sci., v. 36, p. 339-356, 1985.

DODGE, R. E.; ALLER, R. C.; THOMPSON, J. Coral growth related to resuspension of bottom sediments. Nature, v. 247, p. 574-577, 1974.

DODGE, R. E.; VAISNYS, J. R. Coral populations and growth patterns: responses to sedimentation and turbidity associated with dredging. J. mar. Res., v. 35, p. 715730,1977

DUTRA, L. X. C.; KIKUCHI, R. K. P.; LEÃO, Z. M. A. N. Effects of sediment accumulation on reef corals from Abrolhos, Bahia, Brazil. J. coast. Res., Special issue, v. 39, p. 633-638, 2006.

DYTHAM, C. Choosing and using statistics: a biologist's guide. Oxford: Blackwell Science, 1999. 218 p.

EDMUNDS, P. J.; DAVIES, O. S. An energy budget for Porites porites (Scleractinia), growing in a stressed environment. Coral Reefs, v. 8, p. 37-43, 1989.

FRANCINI-FILHO, R.B.; MOURA, R.L. Predation on the toxic zoanthid Palythoa caribaeorum by reef fishes in the Abrolhos Bank, eastern Brazil. Braz, J. Oceanogr., v. 58, n. 1, p. $77-79,2010$

FOSTER, A. B. Environmental variation in skeletal morphology within the Caribbean reef corals Montastrea annularis and Siderastrea siderea. Bull. mar. Sci., v. 30, p. 678-709, 1980.
GARZÓN-FERREIRA, J., CORTÉS, J., CROQUER, A., GUZMÁN, H., LEÃO, Z., RODRIGUEZ-RAMIREZ, A. Status of coral reefs in Southern Tropical America in 2000-2002: Brazil, Colombia, Panama, and Vezezuela. In: WILKINSON, C. (Ed.). Status of coral reefs of the world. Queensland: Australian Institute of Marine Science, p. 343-360. 2002.

HAYWICK, D. W.; MUELLER, E. M. Sediment retention in encrusting Palythoa spp. - a biological twist to a geological process. Coral Reefs, v. 16, p. 39-46, 1997.

HUBBARD, D. K. Reefs as dynamic systems. In: BIRKELAND, C. (Ed.). Life and death of coral reefs. New York: Chapman \& Hall, p 43-67. 1997.

HUGHES, T.P. Community structure and diversity of coral reefs: the role of history. Ecology, v. 70, p. 275-279, 1989.

KNOPPERS, B., EKAU, W., FIGUEIREDO, JR., A. G.; SOARES-GOMES, A. Zona costeira e plataforma continental do Brasil. In: PEREIRA, R. C.; SOARESGOMES, A. (Ed.). Biologia Marinha. Rio de Jnaeiro: Interciência, p. 353-361. 2002.

KNOPPERS, B.; MEYERHOFER, M.; MARONE, E.; DUTZ, J.; LOPEZ, R.; LEIPE, T.; CAMARGO, R. Compartments of the pelagic system and material exchange at the Abrolhos Bank coral reef, Brazil. Arch. Fish. mar. Res., v. 47, p. 285-306, 1999.

LABOREL, J. Les peuplements de Madréporaires des cotes tropicales du Brésil. Annls Univ. Abidjan, v. EII, n. 3, p. $1-261,1970$.

LARCOMBE, P.; WOOLFE, K. J. Increased sediment supply to the Great Barrier Reef will not increase sediment accumulation at most coral reefs. Coral Reefs, v. 18 , p. $163-169,1999$.

LARCOMBE, P.; COSTEN, A.; WOOLFE, K. J. The hydrodynamic and sedimentary setting of nearshore coral reefs, central Great Barrier Reef shelf, Australia: Paluma Shoals, a case study. Sedimentology, v. 48, p. 811-835, 2001

LASKER, H. R. Sediment rejection by reef corals: the roles of behaviour and morphology in Montastrea cavernosa (Linnaeus). J. expl mar. Biol. Ecol., v. 47, p. 77-87, 1980

LEÃO, Z. M. A. N.; GINSBURG, R. N. Living reefs surrounded by siliciclastic sediments: the Abrolhos coastal reefs, Bahia, Brazil. Proc. 8th INTERNATIONAL CORAL REEF SYMPOIUM, 8., 1997. Proceedings... v. 2, 1997. p. 1767-1772.

.LEÃO, Z. M. A. N.; BITTENCOURT, A. C. S. P.; DOMINGUEZ, J. M. L.; NOLASCO, M. C.; MARTIN, L. The effects of Holocene sea level fluctuations on the morphology of the Brazilian coral reefs. Rev. Bras. Geociênc., v. 15, p. 154-157, 1985.

LEÃO, Z. M. A. N.; ARAUJO, T. M. F.; NOLASCO, M. C. The coastal reefs of the coast of eastern Brazil. INTERNATIONAL CORAL REEF SYMPOSIUM, 6., 1988. Proceedings ... v. 3, 1988. p. 339-347.

LEÃO, Z. M. A. N.; KIKUCHI, R. K. P.; MAIA, M. P., LAGO, R. A. L. A catastrophic coral cover decline since 3,000 years B. P., northern Bahia, Brazil. INTERNATIONAL CORAL REEF SYMPOSIUM, 8., 1997.Proceedings... v. 1, p. 583-588. 1997.

LEÃO, Z. M. A. N.; DUTRA, L. X. C.; SPANÓ, S. A rapid biodiversity assessment of the Abrolhos Bank: the 
characteristics of bottom sediments. RAP Bull. biol. Assess., v. 38, p. 75-81, 2006.

LESSA, G. C.; CIRANO, M. On the circulation of a coastal channel within the Abrolhos Coral-Reef System Southern Bahia $\left(17^{\circ} 40^{\prime}\right.$ 'S), Brazil. J. coast. Res., Special issue, v. 39, p. 450-453, 2004.

MAIDA, M.; COLL, J. C.; SAMMARCO, P. W. Shedding new light on scleractinian coral recruitment. J. expl mar. Biol. Ecol., v. 180, p. 189-202, 1994.

MARTIN, L.; FLEXOR, J. M.; BLITZKOW, D.; SUGUIO, $\mathrm{K}$. Geoid change indications along the Brazilian coast during the last 7000 years. In: INTERNATIONAL CORAL REEF SYMPOSIUM, 5., 1985. Proceedings.. v.3, 1985. p. 85-90.

MILLS, M. M.; SEBENS, K. P. Particle ingestion efficiency of the coral Siderastrea siderea and Agaricia agaricites: effects of flow speed and sediment loads. INTERNATIONAL CORAL REEF SYMPOSIUM, 8., 1997. Proceedings... v. 2, 1997. p. 1059-1064.

MUZUKA, A. N. N.; DUBI, A. M.; MUHANDO, C. A.; SHAGHUDE, Y.W. Impact of hydrographic parameters and seasonal variation in sediment fluxes on coral status at Chumbe and Bawe reefs, Zanzibar, Tanzania. Estuar. coast. Shelf. Sci., v. 89, p. 137-144, 2010.

NZALI, L. M.; JOHNSTONE, R. W.; MGAYA, Y. D. Factors affecting scleractinian coral recruitment on a nearshore reef in Tanzania. Ambio, v. 27, p. 717-722, 1998.

POTTS, D. C.; JACOBS, J. R. Evolution of reef-building scleractinian corals in turbid environments: a paleoecological hypothesis. In: INTERNATIONAL CORAL REEF SYMPOSIUM, 9., 2002. Proceedings... v. 1, p. 249-254, 2002.

PRATES, A. P. L. Atlas dos recifes de coral nas unidades de conservação brasileiras. Brasília, DF: MMA, SBF, 2006. $177 \mathrm{p}$.

RICE, S. A.; HUNTER, C. L. Effects of suspended sediment and burial on scleractinian corals from west central Florida patch reefs. Bull. mar. Sci., v. 51, p. 429-442, 1992.

RIEGL, B. Effects of sand deposition on scleractinian and alcyonacean corals. Mar. Biol., v. 121, p. 517-526, 1995.

ROGERS, C. S. Sublethal and lethal effects of sediments applied to common Caribbean reef corals in the field. Mar. Pollut. Bull., v. 14, p. 378-382, 1983.

ROGERS, C. S. Responses of coral reefs and reef organisms to sedimentation. Mar. Ecol. Prog. Ser., v. 62, p. 185202, 1990 .

SEBENS, K. P. Competition for space: growth rate, reproductive output, and escape in size. Am. Nat., v. 120, p. 189-197, 1982

SEGAL, B.; CASTRO, C. B. A proposed method for coral cover assessment: a case study in Abrolhos, Brazil. Bull. mar. Sci., v. 69 , p. 487-496, 2001
SEGAL, B.; EVANGELISTA, H.; KAMPEL, M.; GONÇALVES, A. C.; POLITO, P. S.; SANTOS, E. A. Potential impacts of polar fronts on sedimentation processes at Abrolhos coral reef (South-West Atlantic Ocean/Brazil). Continent. Shelf. Res., v. 28, p. 533$544,2008$.

SOFONIA, J. J.; ANTHONY, K. R. N. High-sediment tolerance in the reef coral Turbinaria mesenterina from the inner Great Barrier Reef lagoon (Australia). Estuar. coast. Shelf. Sci. 78, 748-752, 2008.

SPIOTVOLL, E. STOLINE, M. R. An extension of the Tmethod of multiple comparison to include the cases with unequal sample sizes. J. Am. Stat. Assoc., v. 68, p. 976-978, 1973

STAFFORD-SMITH, M. G.; ORMOND, R. F. G. Sedimentrejection mechanisms of 42 species of Australian Scleractinian corals. Aust. J. mar. Freshwat. Res., v. 43, p. 683-705, 1992.

STAMPAR, S. N., SILVA, P. F., LUIZ, JR. O. J. Predation on the zoanthid Palythoa caribaeoroum (Anthozoa, Cnidaria) by a Hawksbill turtle (Eretmochelys imbricata) in Southeastern Brazil. Mar. Turtle Newsl., v. 117, p. 3-5, 2007.

STORLAZZI, C. D.; FIELD, M. E.; BOTHNER, M. H.; PRESTO, M. K.; DRAUT, A. E. Sedimentation processes in a coral reef embayment: Hanalei Bay, Kauai. Mar. Geol., v. 264, p. 140-151, 2009.

SUCHANEK, T. H.; GREEN, D. J. Interspecific competition between Palythoa caribaeorum and other sessile invertebrates on St.Croix Reefs, U.S. Virgin Islands. In: INTERNATIONAL CORAL REEF SYMPOSIUM, 4., 1981. Proceedings... v. 2, p. 679-684. 1981.

SUMMERHAYES, C. P.; MELO U.; BARRETTO, H. T. The influence of upwelling on suspended matter and shelf sediments off Southeastern Brazil. J. Sediment. Petrol., v. 46, p. 819-828, 1976.

TOMASCIK, T.; SANDER, F. Effects of eutrophication on reef-building corals. Mar. Biol., v. 94, p. 53-75, 1987.

UNDERWOOD, A. J. Experiments in Ecology: Their logical design and interpretation using analysis of variance. Cambridge: Cambridge University Press, 504 p. 1997.

WOOD, R.; OPPENHEIMER, C. Spur and groove morphology from a Late Devonian reef. Sediment. Geol., v. 133, p. 185-193, 2000.

ZAR, J. H. Biostatistical analysis. 4th ed. Upper Saddle River, N. J.: Prentice Hall, 1999. 663 p.

(Manuscript received 18 February 2011; revised 2 December 2011; accepted 30 January 2012) 